\title{
PERAN PUSTAKAWAN DALAM MENGONTROL PENGOLAHAN BAHAN PUSTAKA DI DINAS KEARSIPAN DAN PERPUSTAKAAN KOTA MATARAM
}

\author{
Amin Saleh ${ }^{1}$, Hidayatul Aini² \\ Jurusan Ilmu Perpustakaan, Fakultas Ilmu Sosial dan Ilmu Politik \\ Universitas Muhammadiyah Mataram \\ Email:cukum4amin@gmail.com
}

\begin{tabular}{l} 
INFO ARTIKEL \\
\hline Riwayat Artikel: \\
Diterima:...-...-... \\
Disetujui:...-...-... \\
\end{tabular}

Kata Kunci:

Pengolahan, Pustakawan, Perpustakaan.

\begin{abstract}
Penelitian tentang Peran Pustakawan Dalam Mengontrol Pengolahan Bahan Pustaka di Dinas Kearsipan dan Perpustakaan Kota Mataram, dengan masalah a) bagaimana proses pengolahan bahan pustaka, b) kendala yang dihadapi dalam melakukan kegiatan pengolahan dan c) upaya dalam menghadapi kendala. Metode penelitian yang digunakan adalah metode kualitatif deskriptif dengan tekhnik pengumpulan data yang digunakan adalah a) observasi, b) wawancara, c) studi pustaka dan d) dokumentasi dengan, sementara yang menjadi informan adalah pustakawan di perpustakaan kota mataram yang berjumlah 8 orang.
\end{abstract}

ABSTRAK

\begin{abstract}
Hasil penelitian menunjukkan pengolahan bahan pustaka dimulai dari kegiatan inventaris, mencari subyek, klasifikasi, katalog serta memenuhi kelengkapan buku. Artinya pustakawan yang bekerjasama dalam proses pengolahan bahan pustaka di Perpustakaan Kota Mataram dapat berjalan dengan maksimal. Adapun kegiatan pengolahan bahan pustaka meliputi inventaris, klasifikasi, katalogisasi, pemberian kelengkapan buku. Beberapa kendala yang dihadapi dalam kegiatan pengolahan diantaranya, masih kurangnya pustakawan yang bertugas dalam pengolahan, kurangnya anggaran, perbedaan pendapat pustakawan dalam menentukan nomor kelas dan pelatihan terhadap pustakawan. Upaya yang dilakukan untuk menghadapi kendala memaksimalkan dan mengajukan penambahan pustakawan, menambah jumlah anggaran, dan meningkatkan kerjasama antar pustakawan.
\end{abstract}

\section{A. LATAR BELAKANG}

Pesatnya perkembangan tekhnologi pada zaman ini menjadikan perpustakaan sebagai lembaga yang sangat dibutuhkan dalam setiap program pendidikan, pengajaran serta penelitian dalam setiap lembaga-lembaga atau instansiinstansi lainnya. Tuntutan zaman dari waktu ke waktu mengharuskan manusia untuk cepat dalam memperoleh suatu informasi demi perubahan masa depan menjadi lebih baik. menurut Sutabri, 2015 : 15 mengatakan bahwa "Informasi adalah sebuah istilah yang tidak tepat pemakainya secara umum. Informasi dapat berupa data mentah, data tersusun, kapasitas sebuah saluran komunikasi dan sebagainya."

Kebutuhan manusia terhadap informasi serta ilmu pengetahuan semakin hari semakin

\footnotetext{
${ }^{1}$ Wiji Suwarno, 2010, Ilmu Perpustakaan dan Kode Etik Pustakawan, hlm. 42
}

berkembang. Namun tidak jarang dari mereka lebih memilih untuk mendapatkan informasi secara instan dan cepat melalui internet dibandingkan mencari informasi di perpustakaan, karena menurut pandangan beberapa orang, mereka beranggapan bahwa perpustakaan merupakan tempat yang tidak menarik, membosankan, dan didalamnya terdapat banyak kumpulan buku-buku tua yang berdebu dan sebagainya. Padahal sebaliknya, jika seseorang memilih untuk mencari informasi di perpustakaan, akan banyak sekali informasi yang mereka dapatkan dan sumbernya dapat di pertanggungjawabkan.

Perpustakaan Kota Mataram merupakan salah satu bentuk perpustakaan umum, dimana perpustakaan umum ini berfungsi untuk melayani seluruh masyarakat tanpa membedakan status, suku, jenis kelamin, usia, pekerjaan, sosial-ekonomi dan sebagainya. Perpustakaan Kota memberikan 
kesempatan bagi siapapun dan dari kalangan manapun untuk memperoleh informasi yang mereka butuhkan. Dalam Undang-Undang RI No. 43 Tahun 2007 pasal 20, menyatakan bahwa "Perpustakaan umum adalah perpustakaan yang diperuntukkan bagi masyarakat luas sebagai sarana pembelajaran sepanjang hayat tanpa membedakan umur, jenis kelamin, suku, ras, agama dan status social-ekonomi."

Dalam pernyataan yang dikemukakan oleh Sulistyo Basuki, juga menyatakan bahwa yang termasuk kelompok perpustakaan umum adalah perpustakaan wilayah, perpustakaan kota madya, perpustakaan kabupaten, perpustakaan kecamatan, perpustakaan desa, perpustakaan umum masyarakat dan perpustakaan keliling. Oleh karena itu untuk membantu perpustakaan dalam mencapai tujuannya, maka perlu diadakannya pengolahan bahan pustaka.2

Pengolahan bahan pustaka merupakan salah satu kegiatan yang sangat penting didalam perpustakaan. Menurut P. Sumardji (1993:25) menyatakan bahwa"Kegiatan pengolahan bahan koleksi adalah kegiatan mempersiapkan bahan koleksi yang telah diperoleh, agar dengan mudah dapat diatur di tempat-tempat atau rak-rak penyimpanan sehingga memudahkan pula untuk dilayankan kepada para pemakai koleksi perpustakaan."

Jadi, kegiatan pengolahan merupakan kegiatan yang sangat penting yang harus ada di perpustakaan, dengan tujuan agar memudahkan pemustaka dan pustakawan dalam menemukan kembali koleksi.

Berdasarkan observasi yang telah dilakukan 1 Maret hingga 23 Mei 2019 bahwa dalam kegiatan pengolahan bahan pustaka meliputi kegiatan inventaris, memberikan stempel kepemilikan Dinas Kearsipan dan Perpustakaan Kota Mataram, melakukan pencatatan nomer pada buku induk mulai dari tanggal masuk buku, nomor judul dan nomor induk, judul buku, pengarang, tahun terbit, penerbit, asal, harga, cetakan dan keterangan. Kegiatan selanjutnya adalah menentukan nomer kelas dengan menggunakan buku klasifikasi yang sudah ditentukan dalam hal ini Perpustakaan Kota Mataram menggunakan 2 (dua) buku klasifikasi yakni Dewey Decimal Classification oleh Drs. Towa P. Hamakonda dan Terjemahan Klasifikasi Desimal Dewey Ringkas Edisi ke-14 yang terbitkan oleh Perpustakaan Nasional RI kemudian aplikasi Dalam pengolahani Perpustakaan Kota Mataram menggunakan system INLISLITE versi 3.1

Perpustakaan umum kota mataram sebagai salah satu instansi pemerintah yang di fokuskan bergerak dalam bidang informasi memiliki pemustaka aktual dan potensial dan secara umum semua masyarakat sehingga secara tidak langsung di harapkan semua terlibat dalam mensukseskan dan memanfaatkan perpustakaan salah satunya lembaga pendidikan baik negeri maupun swaasta sehingga secara kalender akademik dan kalender pendidikan banyak sekolah-sekolah dan perguruan tinggi menempatkan siswa dan mahasiswanya praktek di perpustakaan. kemudian perpustakaan melakukan pendampingan terhadap siswa dan mahasiswa tersebut. Dengan demikian kontribusi yang mereka berikan sangat nyata namun tetap harus berada dalam pengawasan pustakawan khususnya bagian pengolahan.

\section{B. RUMUSAN MASALAH}

Berdasarkan latar belakang di atas, dapat di rumusan masalah sebagai berikut :

1. Bagaimana proses pengolahan bahan pustaka di Dinas Kearsipan dan Perpustakaan Kota Mataram?

2. Apa saja kendala dalam kegiatan pengolahan bahan pustaka di Dinas Kearsipan dan Perpustakaan Kota Mataram ?

3. Bagaimana upaya perpustakaan dalam menghadapi kendala yang dihadapi pada 
kegiatan pengolahan bahan pustaka di Dinas Kearsipan Perpustakaan Kota Mataram?

\section{Tujuan dan Manfaat}

1. Untuk mengetahui bagaimana proses pengolahan bahan pustaka di Perpustakaan Kota Mataram.

2. Untuk mengetahui apa saja kendala pengolahan bahan pustaka di Perpustakaan Kota Mataram.

3. Untuk mengetahui upaya perpustakaan dalam menghadapi kendala yang dihadapi pada kegiatan pengolahan bahan pustaka di Perpustakaan Kota Mataram.

\section{TINJAUAN PUSTAKA}

\section{Definisi Pengolahan Bahan Pustaka}

Bahan pustaka disebut juga dengan koleksi perpustakaan. Dimana bahan pustaka terdiri dari beberapa : 1) karya cetak seperti buku, majalah, surat kabar, disertasi, laporan, 2) karya non-cetak atau karya rekam yang berupa audiovisual, kaset, video, rekaman, 3) berbentuk film seperti microfilm dan 4) karya yang berbentuk koleksi digital seperti disket, e-book, e-journal, CD-ROM dan sebagainya.

Jadi koleksi perpustakaan atau bahan pustaka merupakan semua hasil karya tulis, karya cetak, karya rekam yang dikumpulkan kemudian diolah secara sistematis dengan tujuan untuk disajikan kepada masyarakat agar berdaya guna untuk memenuhi kebutuhan informasi masyarakat.

Pengolahan bahan pustaka merupakan salah satu kegiatan yang ada diperpustakaan bertujuan untuk melakukan pengaturan bahan pustaka agar dapat disimpan ditempat tertentu yang sesuai dengan aturan, sehingga hal tersebut memudahkan user untuk menemukan bahan pustaka yang dicari dan dibutuhkan.

Menurut Qalyubi (2007 : 51) mengemukakan tentang pengolahan bahan pustaka adalah"Setiap perpustakaan memiliki tugas menyediakan bahan pustaka serta mengolahnya agar dapat disajikan kepada pengguna sehingga bahan pustaka tersebut dapat bermanfaat bagi pengguna perpustakaan. Sebelum bahan pustaka tersebut dilayankan kepada pengguna, terlebih dahulu diolah dan disusun secara sistematis untuk memudahkan pengguna dalam memperoleh informasi yang dibutuhkan."

Adapun langkah-langkah pengolahan bahan pustaka, diantaranya sebagai berikut :

1) Menyetempel

2) Mencatat dalam buku induk (pemberian nomer buku)

3) Membuat deksripsi catalog

4) Penentuan subyek, diantaranya memberi nomer kelas sesuai aturan DDC

5) Pengetikan label, kartu buku serta kantong buku

6) Penempelan : slip pengembalian, kantong kartu buku, label buku, label warna

7) Penyampulan

8) Menyusun bahan pustaka yang sudah selesai di olah pada rak yang sesuai dengan nomer kelas.

9) Bahan pustaka sudah dapat di pinjam dan digunakan.

\section{Proses Pengolahan Bahan Pustaka}

Proses pengolahan bahan pustaka dimulai dari kegiatan pemberian stempel pada buku serta mencatat dalam buku induk (pemberian nomer buku) atau biasa disebut dengan kegiatan inventaris. Kegiatan ini merupakan langkah pertama yang dilakukan ketika memulai proses pengolahan bahan pustaka.

1) Inventaris

Inventaris merupakan pencatatan bahan pustaka baru baik berupa buku, CD, majalah dan sebagainya yang dimiliki oleh perpustakaan baik berasal dari pembelian maupun hadiah, yang ditulis dalam buku 
khusus yang disebut dengan buku induk. Inventaris pada perpustakaan dibuat dengan tujuan untuk dapat mengetahui kepemilikan sebuah bahan pustaka sehingga memudahkan dalam membuat laporan, atau pemeriksaan statistiknya. Dalam hal ini yang diperlukan dalam menginventaris adalah buku inventaris dan cap stempel perpustakaan.

2) Klasifikasi

Klasifikasi adalah suatu kegiatan yang mengelompokkan sesuatu benda yang memiliki beberapa ciri yang sama dengan tujuan untuk memudahkan dalam penyimpanan dan pencarian kembali. Secara umum, klasifikasi diartikan sebagai pengelompokkan. Menurut Kamus Besar Bahasa Indonesia (KBBI) 1997) "Klasifikasi adalah penyusunan bersistem dalam kelompok atau golongan menurut kaidah atau standar yang ditetapkan."

Banyak system klasifikasi yang digunakan oleh perpustakaan, diantaranya yang paling terkenal adalah Dewey Decimal Classification (DDC), Universal Decimal Classification (UDC), dan Library of Congress Classification (LCC). Dari ketiga system tersebut, DDC lah yang menjadi pilihan utama dalam proses mengklasifikasi karena dianggap lebih mudah.

3) Katalogisasi

Katalogisasi merupakan kegiatan menentukan deskripsi bibliografi dan tajuk dengan mengidentifikasi fisik dokumen berdasarkan system/peraturan yang telah ditentukan. Adapun pedoman yang paling popular digunakan dalam membuat katalog adalah Anglo-American Cataloguing Rules edisi 2 atau disingkat dengan AACR2. AACR2 merupakan perangkat yang digunakan untuk semua jenis bahan pustaka yang bersifat fleksibel, artinya pada beberapa aturan tertentu boleh digunakan atau tidak. Selain itu juga, katalog dibuat untuk mempermudah dalam mencari dan menemukan bahan pustaka yang dibutuhkan oleh pengunjung perpustakaan.

4) Kelengkapan Fisik Buku

Adapun kelengkapan fisik buku dalam proses pengolahan bahan pustaka adalah sebagai berikut :

1. Label kode buku

Setiap buku harus mempunyai :

a. Label kode pustaka (buku)

b. Label warna, berfungsi untuk memudahkan mencari buku tersebut pada tempat penyimpanan, dan untuk membedakan buku tersebut dengan yang lainnya.

2. Label kode buku ini diketik, yang kemudian direkatkan pada punggung buku dengan jarak $3 \mathrm{~cm}$ dari bawah. Jika tidak dapat ditempelkan pada punggung buku. Jika buku tipis, maka label kode buku tersebut direkatkan pada kulit muka buku dimulai dari punggung buku dengan jarak $3 \mathrm{~cm}$ dari bawah. Selanjutnya ditutup menggunakan isolasi bening.

Keterangan yang ada didalam label kode buku adalah sebagai berikut :
a. Nomor klasifikasi
b. Tiga huruf pertama dari nama pengarang
c. Satu huruf pertama dari judul

3. Label warna direkatkan pada punggung buku dibawah label kode buku.

\section{E. METODE PENELITIAN}

Penelitian ini menggunakan metode kualitatif dengan pendekatan kualitatif deskriptif karena metode penelitian kualitatif merupakan suatu langkah yang digunakan dalam memecahkan suatu masalah menggunakan beberapa data-data yang berupa narasi sementara pendekatan deskriptif merupakan suatu langkah atau metode dalam 
penelitian yang menggambarkan suatu objek atau subyek berdasarkan fakta-fakta yang sedang terjadi dilapangan tentunya yang berkaitan dengan penelitian.

Metode penelitian ini juga merupakan caracara atau ajaran yang digunakan ketika akan melakukan suatu penelitian. Seperti yang diketahui, metode penelitian ini memiliki berbagai macam persyaratan yang ketat untuk bisa memberikan atau memperoleh suatu kebenaran dari data tersebut. Adapun persyaratan dalam metode penelitian ini berupa data-data, fakta-fakta, obyek, subyek serta hasil wawancara berupa sesi tanya dan jawab yang dilakukan langsung dengan dua orang pustakawan yang bertugas dalam bidang pengolahan.

Adapun tekhnik pengumpulan data dilakukan dengan cara Observasi, Wawancara, Dokumentasi dan Studi Pustaka. Sementara Lokasi Dan Waktu Penelitian dilakukan di Perpustakaan dan kearsipan Umum Kota Mataram, Jl. Gunung Rinjani No. 1 Dasan Agung Mataram. Tlp. (o370) 649245. Dilakukan selama 3 bulan mulai tanggal 1 Maret 2019 sampai 23 Mei 2019.

\section{F. PEMBAHASAN}

\section{Proses Pengolahan Bahan Pustaka}

Pengolahan biasanya disebut dengan proses atau processing, kegiatan ini dilakukan mulai dari koleksi diterima diperpustakaan sampai dengan siap dimanfaatkan oleh pemustaka. Sementara pustakawan di Perpustakaan Kota Mataram berjumlah 8 orang, namun yang bertugas untuk bagian pengolahan ada 4 orang. Dalam sehari pustakawan dapat mengelolah 15-20 buku dengan jam kerja yang dimulai pada jam o8:oo hingga 11:00 siang, dilanjutkan kembali pada jam 14.00 hingga 13.45 sore. Namun apabila secara kebetulan ada siswa/i atau mahasiswa/i buku yang berhasil diolah bisa mencapai 25-35 perharinya sehingga Perpustakaan Kota Mataram dapat menyelesaikan buku yang diolah dengan waktu yang lebih cepat.
Adapun beberapa proses pengolahan yang diterapkan diantaranya adalah sebagai berikut:

\section{1) Inventaris}

Menurut ibu Nurhayati, SE. selaku pustakawan fungsional yang bertugas dibagian pengolahan mengatakan bahwa kegiatan invetaris dimulai dari pengecekan bahan pustaka yang akan diolah, pemberian stempel instansi dan stempel rahasia kepemilikan dan pencatan nomor buku di buku induk.Sedangkan menurut ibu Sulhaini, A.Md, inventaris merupakan kegiatan yang paling utama dilakukan ketika akan memulai mengolah bahan pustaka. Adapun kegiatan inventaris meliputi pengecekan koleksi, pemberian stempel dan mencatat nomor buku di buku induk. Biasanya buku induk untuk pembelian pribadi dengan hadiah yang didapatkan dari Perpustakaan Nasional RI dipisahkan.

Dalam kegiatan inventaris bahan pustaka hal pertama yang harus dilakukan adalah sebagai berikut :

1. mengecek bahan pustaka, apakah diterima dengan baik dan lengkap atau tidak.

2. Memberikan stempel dinas atau instansi pada tiga halaman berbeda yakni 1) halaman judul, 2) halaman tengah dan 3) halaman terakhir judul tanpa mengganggu teks yang ada. Selain itu pula memberikan stempel rahasia kepemilikan sesuai dengan kesepakatan instansi, biasanya stempel rahasia berada pada halaman 15 .

3. Pencatatan dalam buku induk. Setiap buku yang diterima oleh Dinas Kearsipan dan Perpustakaan Kota Mataram, baik buku yang diterima dari pembelian, sumbangan, hadiah ataupun lainnya wajib untuk dicatat di dalam buku induk. Buku induk pembelian dengan buku induk hadiah perpusnas dibedakan, hal-hal yang dicatat dalam buku induk adalah sebagai berikut : tanggal masuk bahan 
pustaka, nomor judul, nomor induk, judul buku, pengarang, tahun terbit, penerbit, asal, harga, cetakan dan keterangan.

Dalam kolom "keterangan" pada pencatatan buku induk diberi salah satu penjelasan, diantaranya adalah sebagai berikut :

a. Hadiah dari .... (disebutkan nama yang memberikan hadiah)

b. Rusak tidak dipergunakan lagi

c. Hilang dipinjam / dirak buku

Adapun kegiatan invetaris dilakukan dengan tujuan :

1. Memudahkan pustakawan dalam mengetahui jumlah koleksi pengadaan setiap tahunnya.

2. Membantu memudahkan pekerjaan pustakawan dalam membuat laporan tahunan.

3. Memudahkan pustakawan dalam mengawasi jumlah koleksi.

Inventaris bahan pustaka adalah kegiatan pencatatan setiap bahan perpustakaan yang diterima perpustakaan ke dalam buku inventaris atau buku induk sebagai tanda bukti perbendaharaan atau kepemilikan perpustakaan.3

Jadi, kegiatan inventaris merupakan kegiatan pengecekan bahan pustaka dalam keadaan baik dan lengkap, pemberian stempel kepemilikan dan pencatatan nomor induk di buku inventaris.

\section{2) Klasifikasi}

Menurut narasumber, ibu Nurhayati, SE. mengatakan bahwa kegiatan klasifikasi di Perpustakaan Kota Mataram menggunakan 2 (dua) buku pedoman, yakni buku DDC oleh Drs. Towa P. Hamakonda dan Terjemahan DDC Edisi ke-14 yang diberikan langsung dari Perpustakaan Nasional RI. Namun sebelum itu disarankan untuk mencari subyek terlebih dahulu agar memudahkan dalam kegiatan mengkelas.

Sedangkan menurut narasumber kedua, ibu Sulhaini A.Md mengatakan bahwa kegiatan klasifikasi adalah kegiatan yang sedikit susah karena kita harus mencari nomor kelas dengan sangat teliti. Karena jika nomor kelas yang digunakan keliru maka akan menjadi masalah bagi pemustaka dan pustakawan ketika mencari koleksi yang dibutuhkan.

Berikut merupakan jumlah koleksi yang sudah diolah berdasarkan klasifikasi pada tahun 2018 Dewey Decimal Classification oleh Drs. Towa P. Hamakonda, M.L.s J.N.B Tairas dan Terjemahan Klasifikasi Desimal Dewey Ringkas Edisi ke-14 yang diterbitkan oleh Perpustakaan Nasional RI.

Pustakawan yang bertugas dalam menentukan nomor kelas buku adalah ibu Nurhayati dan ibu Sulhaini, A.Md. selaku pustakawan fungsional. Langkah awal proses klasifikasi adalah menentukan subyek buku. Biasanya subyek dapat diketahui melalui judul, daftar isi, atau kata pendahuluan. Jika dari ketiga langkah tersebut masih belum diketahui secara pasti, maka langkah selanjutnya adalah dengan membaca sebagian dari isi buku. Jika langkah ini masih juga belum bisa menemukan subyeknya, sebaiknya menanyakan kepada orang yang ahli dalam bidangnya. Setelah subyek buku diketahui dengan jelas dan pasti, maka langkah selanjutnya dapat ditentukan untuk mencari nomor klasifikasinya dengan cara :

a. Menjadikan indeks relati dalam memperoleh acuan kode klasifikasi bagi subyek buku.

b. Menggunakan pedoman klasifikasi untuk memastikan kode acuan tersebut tepat atau tidak.

c. Nomor kelas harus diusahakan setepat mungkin. 
d. Jika menemukan nomor klasifikasi yang belum tercantum dalam bagian DDC, maka hal yang perlu dilakukan adalah menggunakan nomor klasifikasi dari nomor yang paling mendekati subyeknya.

e. Mengklasifikasi buuku-buku lain seperti klasifikasi buku cerita, biografi, majalah, Koran, kliping ataupun buku referensi.

f. Mencantumkan kode klasifikasi pada halaman judul dan dilengkapi dengan tiga huruf pertama dari pengarang, huruf pertama dari judul buku dan kode buku.

g. Penulisan kode buku disusun berdasarkan aturan, yakni : nomor kelas ditempatkan paling atas, selanjutnya dibawahnya pengarang dan yang paling bawah judul. Untuk buku referensi, diatas kode klasifikasinya ditambahkan huruf "R".

h. Kode klasifikasi yang dipakai sebanyakbanyaknya adalah 7 (tujuh) angka.

Sistem klasifikasi persepuluhan Dewey atau biasa disebut dengan DDC membagi seluruh cabang golongan ilmu pengetahuan, yakni 10 kelas utama. Dimana masing-masing kelas dibagi kembali menjadi 10 devisi, masingmasing devisi dibagi menjadi 10 seksi dan selanjutnya masing-masing seksi dibagi menjadi 10 sub seksi dengan menambahkan angka decimal dibelakang 3 (tiga) angka dasarnya.

Adapun beberapa klasifikasi buku diantaranya adalah ;

1. Klasifikasi buku cerita.

Buku-buku fiksi biasanya dikumpulkan dalam satu kelompok. Buku-buku fiksi ini memiliki nomor kelas tersendiri, diantaranya adalah 028.5 bacaan anak dan remaja; 398 cerita rakyat atau folklore yang meliputi cerita rakyat, sosiologi folklore, dongeng, teka-teki, pribahasa; 808.3 retorika fiksi.

2. Klasifikasi Biografi

Dalam mengklasifikasi biografi terdapat beberapa cara yang cukup mudah diantara adalah menulis huruf "B" yang merupakan singkatan dari biografi, selanjutnya mencantumkan tiga huruf pertama dari nama tokoh yang dikisahkan. Huruf B dapat diganti dengan 920, karena 920 merupakan nomor kelas untuk subyek biografi. Dan perpustakaan tidak boleh menggunakan dua nomor punggung huruf B dan 920 dalam biografi karena dikhawatirkan dapat membingunkan pemustaka ketika mencarinya.

3. Klasifikasi Majalah

Majalah pada umumnya berada pada nomor kelas 050. Namun beberapa majalah yang ada di Dinas Kearsipan dan Perpustakaan Kota Mataram tidak di perlu diberikan nomor kelas, kecuali majalah yang sudah disatukan dan dijilid dianggapnya sebagai buku oleh karena itu harus ada nomor kelas berdasarkan subyek sebagaimana biasanya proses klasifikasi buku.

4. Klasifikasi Koran

Nomor kelas untuk koran adalah 070 yakni pers, jurnalisme, penerbitan, persuratsuratan. Namun pada Dinas Kearsipan dan Perpustakaan Kota Mataram tidak perlu diberikan nomor klasifikasi.

\section{Klasifikasi Kliping}

Kliping yang memiliki subyek yang sama dikumpulkan kemudian dijilid menjadi sebuah buku. Nomor kelas untuk kliping disesuaikan berdasarkan subyeknya.

6. Klasifikasi buku referensi

Buku referensi meliputi ensiklopedi umum, kamus, dan atlas.

Jadi, kegiatan klasifikasi adalah suatu kegiatan pengelompokkan bahan pustaka berdasarkan ciri-ciri yang sama seperti judul, isi, pengarang dan sebagainya menggunakan buku klasifikasi yang sudah ditentukan. 


\section{3) Katalogisasi}

Dari hasil wawancara yang didapatkan dari narasumber (ibu Nurhayati), mengatakan bahwa kegiatan katalogisasi yang ada di Perpustakaan Kota Mataram saat ini sudah termasuk mengikuti perkembangan teknologi dikarenakan telah menggunakan sistem INLISLITE versi 3.1, dimana aplikasi ini merupakan yang terbaru untuk system pengolahan. Jadi ketika kita ingin mengkatalog suatu buku, kita hanya perlu memasukkan datadata yang ada dibuku tersebut ke dalam entri katalog, jika tidak ada data bisa dikosongkan. Selanjutnya memasukkan jumlah eksemplar pada entri katalog. Kelebihan dari aplikasi ini call number, label warna, dan barcode sudah tersedia langsung ketika kita sudah selesai mengkatalog, jadi hal ini mempercepat proses pengolahan yang ada di Perpustakaan Kota Mataram.

Sedangkan menurut ibu Sulhaini, A.Md. mengatakan bahwa kegiatan katalogisasi adalah kegiatan yang dilakukan setelah selesai mengkelas buku. Kegiatan ini dilakukan dengan tujuan memasukkan data-data buku ke komputer, agar ketika kita ingin mencari informasi tentang buku tersebut kita tidak lagi kesusahan untuk mendapatkannya. Selain itu juga, kita dapat mengetahui berapa jumlah koleksi yang sudah diolah beserta jumlah eksemplarnya. Selanjutnya memberikan kelengkapan buku seperti sampul, kartu buku, kantong buku dan slip pengembalian.

Adapun kegiatan yang dilakukan ketika selesai mengklasifikasi adalah membuat katalog. Setiap buku yang diterima di Dinas Kearsipan dan Perpustakaan Kota Mataram oleh bagian pengolahan sangat perlu dicocokkan kembali dengan katalog yang ada, untuk mengetahui apakah buku yang ada merupakan duplikasi atau tidak. Jika buku tersebut merupakan duplikasi, maka yang perlu kita lakukan hanyalah member label, kartu, kantong buku dan slip pengembalian, selain itu pula jumlah eksemplar harus ditambah didalam buku induk. Namun berbeda halnya jika buku tersebut belum pernah masuk ke perpustakaan atau merupakan buku baru, maka akan diolah sesuai dengan prosedur yang ada.

Adapun beberapa langkah-langak untuk membuat katalogisasi pada Dinas Kearsipan dan Perpustakaan Kota Mataram, diantaranya adalah :

1. Menetapkan jenis buku, seperti mengelompokkan buku-buku sesuai dengan jenis atau subyeknya, seperti buku biasa, buku laporan, referensi, bibliografi ataupun majalah.

2. Menentukan pengarang, pengaran disini yang di maksud bisa satu orang, sekelompok orang ataupun lembaga.

3. Menentukan judul. Judul utama wajib dicantumkan dan apabila ada judul tambahan sebaiknya untuk ditulis agar melengkapi data yang sedang dimasukkan kedalam katalog.

4. Impresum, yakni menjelaskan tempat terbit, nama penerbit serta tahun terbit pada buku. Jika tidak diketahui dapat dikosongkan atau dapat menggunakan s.l (sine loco) ketika tempat terbit tidak diketahui, s.a (sine nonime) jika nama penerbit atau penerbit tidak diketahui, dan s.a (sine anno) jika tahun terbitnya tidak diketahui

5. Kolasi menjelaskan beberapa hal seperti jumlah halaman, jumlah jilid, pernyataan ilustrasi, ukuran buku dalam centimeter.

6. Jejakan atau biasa disebut dengan keterangan pada kartu-kartu. Dalam hal ini biasanya yang ada seperti kartu tambahan untuk pengarang, judul, subyek atau seri.

Menurut Rusina Sjahrial Pamuntjak 4, mengatakan bahwa "Katalog adalah daftar barang yang berada pada suatu tempat, dengan demikian katalog perpustakaan adalah daftar pustaka yang ada dalam perpustakaan. Jadi katalogisasi adalah kegiatan menentukan deskripsi bibliografi dan tajuk dengan mengidentifikasi fisik dokumen

${ }^{4}$ Drs. Ahmad Masykuri, MM, 2012, Katalogisasi, hlm. 3 
berdasarkan system/peraturan yang telah ditentukan."

Jadi, kegiatan katalogisasi adalah kegiatan yang dilakukan dengan memasukkan data-data atau menentukan deskripsi bibliografi suatu koleksi dengan tujuan untuk membantu pemustaka dalam menemukan kembali informasi yang diinginkan dengan cepat.

Dari hasil wawancara yang dilakukan dengan ibu Nurhayati, SE. setelah kegiatan katalog selesai. Langkah selanjutnya adalah mengeprint call number yang sudah dilengkapi dengan barcode dan label warna. Lalu setelah itu, memberikan kelengkapan buku seperti kartu buku, kantong kartu buku, dan slip pengembalian. Setelah semua selesai ditempel, langkah selanjutnya menyampul buku menggunakan sampul buku dengan tujuan agar buku tidak mudah rusak jika terkena air atau dimakan rayap.

Adapun kegiatan yang dilakukan setelah mengeprint label kode buku adalah memasang kelengkapan buku. Diantaranya adalah sebagai berikut :

1. Label kode buku

Setiap buku harus memiliki label kode buku dan label warna. Label kode buku yang sudah dilengkapi langsung dengan kode buku, label warna serta barcode yang sudah diketik dan diprint kemudian direkatkan pada punggung buku dengan jarak $3 \mathrm{~cm}$ dari bawah atau 3 jari. Jika punggung buku tidak memungkinkan untuk menempel label, maka boleh ditempel pada kulit muka menggunakan jarak yang sama yakni $3 \mathrm{~cm}$ dari bawah, setelah itu di rekatkan dengan isolasi berwarna bening. Tujuannya adalah agar memudahkan menemukan kembali buku tersebut ketika sudah ada pada rak penyimpanan, dan untuk label warna tujuannya adalah untuk membedakan antara buku itu sendiri dengan buku yang lain.

2. Kartu buku
Setiap bahan pustaka yang ada di perpustakaan kecuali referensi harus dilengkapi dengan kartu buku yang berukuran $8 \times 13 \mathrm{~cm}$. Adapun keterangan yang ada dalam kartu buku adalah nama pengarang dan judul buku, kode buku (call number) dan nomor induk, kolom untuk nomor KTA/ nama peminjam. Kartu buku ditaruh pada bagian belakang yang diselipkan pada kantong kartu buku pada setiap buku yang boleh dipinjam atau dibawa pulang.

3. Kantong kartu buku

Kantong kartu buku merupakan tempat menaruh kartu buku yang direkatkan pada kulit belakang didalam setiap buku. Ukurannya 8,5 x 10,5 cm dengan keterangan nama pengarang dan judul buku, kode buku (call number) dan nomor induk buku.

4. Slip tanggal kembali

Slip tanggal kembali memuat kolom tanggal buku yang harus dikembalikan ke perpustakaan. Slip tanggal kembali ini direkatkan pada kulit belakang bagian dalam buku yang boleh dipinjam, berhadapan dengan kantong kartu buku. Dan ukurannya $9 \times 14 \mathrm{~cm}$.

5. Penyampulan buku

Setiap buku yang sudah di beri label yang berisi kode buku, barcode dan warna kemudian disampul menggunakan warna bening dengan tujuan agar tidak mudah rusak dan kotor.

\section{Kendala Pengolahan Bahan Pustaka}

Adapun beberapa kendala yang terjadi dalam proses pengolahan bahan pustaka di Dinas Kearsipan dan Perpustakaan Kota Mataram adalah sebagai berikut :

1. Sumber Daya Manusia

Pada Perpustakaan Kota Mataram, pustakawannya berjumlah 8 (delapan orang). Namun tidak semuanya berasal dari jurusan perpustakaan asli, melainkan ada yang 
mengikuti beberapa pelatihan atau bimtek sebagai pustakawan. Semenjak tahun 2018 jumlah pengunjungnya mencapai 4.783 orang yang meliputi layanan ruang baca umum, pendidikan pemakai, taman. Dan adapun anggotanya sebanyak 3.537 orang yang berasal dari pelajar atau mahasiswa, pegawai, dan umum. Jika diasumsikan jumlah pustakawan 8 dengan anggota yang aktif 3.537, maka setiap pustakawan melayani sekitar 442 jiwa dalam memberikan pelayanan terkait dengan informasi yang mereka cari atau mereka butuhkan. Dengan jumlah pustakawan yang sedikit ditambah dengan kurangnya keahlian dari beberapa pustakawan dalam proses pengolahan, sehingga hal ini menjadi kendala dalam proses pengolahan bahan pustaka sehingga kegiatan belum bisa dilakukan secara maksimal dan proses pengolahan bahan pustaka terkadang tertunda dalam waktu yang lumayan lama.

Menurut UU No 43 Tahun 2007 tentang Perpustakaan Pasal 29 ayat 1 dan 2, yakni “(Ayat 1) Tenaga perpustakaan terdiri atas pustakawan dan tenaga teknis perpustakan. (Ayat 2) pustakawan sebagai mana yang dimaksud pada ayat 1 harus memenuhi kualisifikasi sesuai dengan standar nasional perpustakaan.

Perpustakaan Kota Mataram, memiliki 8 (delapan) orang pustakawan. Diantaranya 5 (lima) pustakawan diperoleh melalui pendidikan D3 Perpustakaan dan 3 (tiga) lainnya merupakan pelatihan kepustakawan. Namun setiap pustakawan memiliki masing-masing pekerjaan yang berbeda, sehingga pengolahan bahan pustaka berjalan lambat dan belum maksimal.

2. Anggaran

Anggaran merupakan salah satu yang menjadi kendala besar yang dihadapi oleh Dinas Kearsipan dan Perpustakaan Kota Mataram di bidang pengolahan. Katakan saja jika anggaran yang diberikan untuk bidang pengolahan adalah
50 juta setiap tahunnya untuk membeli bahanbahan kelengkapan buku. Mungkin jika pengolahan bahan pustaka hanya berasal dari pengadaan Perpustakaan Kota Mataram, maka kebutuhan untuk pengolahan dirasa akan tercukupi.

Namun berbeda lagi ceritanya jika ditambah dengan koleksi yang berasal dari hibah Perpustakaan Nasional, maka alat dan bahan pengolahan akan kekurangan. Hal ini dikarenakan semua buku yang masuk ke dalam Perpustakaan Kota Mataram akan di olah sesuai dengan aturan pengolahan perpustakaan Kota Mataram, misalnya dalam pembelian bahanbahan untuk menyampul buku, kantong buku, slip pengembalian buku masih kurang. Dan juga jika ada buku tambahan dari luar, pustakawan tidak bisa bekerja karena akan menyebabkan pekerjaan sebelumnya tertunda yang terjadi karena adanya pemeriksaan bahan pustaka serta alat bahan yang termasuk kurang, oleh hal ini menjadi kendala pustakawan dalam melakukan pengolahan.

Dalam UU No 43 Tahun 2007 tentang Perpustakaan pasal 39 ayat 2, menyatakan bahwa"Pemerintah dan pemerintah daerah mengalokasi anggaran perpustakaan dalam anggaran pendapatan dan belanja negara (APBN) dan anggaran pendapatan dan belanja daerah (APBD)."

Jadi, anggaran merupakan salah satu kendala yang paling sering dihadapi oleh Perpustakaan Kota Mataram. Seharusnya dalam hal ini pemerintah dapat mengalokasikan anggaran perpustakaan dalam APBN dan APBD sesuai dengan UU yang berlaku sehingga kegiatan pengolahan bahan pustaka di Perpustakaan Kota Mataram dapat berjalan dengan seefektif mugkin.

3. Mengkelas buku dan Menentukan Subyek

Adapun jumlah pustakawan yang ada di perpustakaan Kota Mataram adalah 8 (delapan) 
orang. Masing-masing dari mereka memiliki tugas masing-masing diperpustakaan yang berbeda. Pustakawan fungsional yang bertugas dalam mengkelas buku adalah ibu Nurhayati dengan di bantu oleh ibu Sulhaini dan ibu Zohariah. Namun dari ketiga pustakawan tersebut sering terjadi perbedaan pendapat dalam proses mengkelas, contohnya ketika mengkelas buku untuk anak-anak sering sekali berbeda pendapat seperti penggunaan nomor kelas 028.5 untuk bacaan anak dan remaja, 398 untuk cerita rakyat, folklore atau kumpulan cerita dongeng dan 808.3 untuk fiksi Indonesia.

Selain itupula, berbagai macam judul buku yang ada di perpustakaan menyebabkan terjadinya kesulitan dalam menentukan subyek untuk mencari nomor kelas. Sehingga ini sangat perlu adanya bimbingan oleh ahli dari bidangnya agar tidak menyebabkan kesalahan dalam menentukan subyek bahan pustaka. Sama juga halnya dengan mahasiswa PKL, seringkali kami kesulitan dalam menentukan subyek ketika proses pengolahan. Namun hal ini tidak membuat kami ragu untuk bertanya kepada pustakawan asli yang lebih memahaminya.

Menurut UU Tentang Perpustakaan Pasal 1 ayat 8 menyatakan bahwa "Pustakawan adalah seseorang yang memiliki kompetensi yang diperoleh melalui pendidikan dan/atau pelatihan kepustakawanan serta mempunyai tugas dan tanggung jawab untuk melaksanakan pengolahan dan pelayanan perpustakaan.”

Oleh karena itu, seorang pustakawan yang bertugas dalam mengkelasifikasi di Perpustakaan Kota Mataram adalah mereka yang benar-benar memiliki kompetensi atau ahli dalam bidangnya. Namun perbedaan pendapat seringkali terjadi dalam kegiatan mengkelas.

\section{Pelatihan Tenaga Pustakawan}

Kurangnya pelatihan terhadap pustakawan juga menjadi salah satu kendala yang ada di
Perpustakaan Kota Mataram. Padahal pelatihanpelatihan ini sangat dibutuhkan kedepannya agar pustakawan dapat bekerja lebih professional terutama dalam bidang pengolahan. Sehingga pengolahan dapat berjalan dengan maksimal. Menurut keterangan yang diberikan oleh ibu Nurhayati, SE. selaku pustakawan fungsional, pelatihan untuk pustakawan di adakan 2 (tiga) bulan sekali yang di adakan di Dinas Kearsipan dan Perpustakaan Kota Mataram. Selain itu juga, terkadang beberapa pustakawan diberikan tugas dinas untuk mengikuti pelatihan atau pendidikan beberapa di perpustakaan luar kota seperti Perpustakaan Nasional RI, Perpustakaan Yogyakarta dan sebagainya.

\section{Upaya Perpustakaan Dalam Menghadapi Kendala}

Adapun upaya-upaya yang dilakukan dalam menghadapi kendala-kendala yang di hadapi pada kegiatan pengolahan bahan pustaka di Dinas Kearsipan dan Perpustakaan Kota Mataram, adalah

Pertama, dengan menambah jumlah pustakawan ahli atau yang berasal dari jurusan perpustakaan asli, sehingga dengan adanya penambahan jumlah pustakawan ini diharapkan proses pengolahan dapat berjalan dengan maksimal serta dapat meminimalisir kendala yang terjadi dalam bidang pengolahan. Sehingga bahan pustaka yang diolah dapat dengan cepat disebarkan dan digunakan oleh pemustaka yang membutuhkan.

Selanjutnya, untuk masalah anggaran. Sebaiknya dari perpustakaan sendiri dapat menambah jumlah anggaran baik sebesar 10\% hingga 20\% dari jumlah anggaran sebelumnya, dengan maksud agar dapat mencukupi kebutuhan alat dan bahan proses pengolahan bahan pustaka. Atau bisa dengan bekerjasama dengan bidang keuangan dalam mencocokkan terlebih dahulu alat dan bahan apa saja yang dibutuhkan dalam proses bahan pustaka sesuai dengan jumlah koleksi yang akan diolah baik yang 
berupa pengadaan dari perpustakaan itu sendiri ataupun koleksi hibah dari PerpusNas RI.

Seharusnya pustakawan yang bertugas dalam mengkelas dapat bekerjasama dengan baik dalam menentukan nomor kelas, selain pekerjaan dapat menjadi lebih efesien dan efektif. Hal ini juga dapat meminimalisir kesalahan dalam menentukan nomor kelas sehingga ketika terjadi penelusuran kembali pada suatu informasi atau bahan pustaka yang dibutuhkan dapat dicari dengan cepat dan tepat. Karena jika nomor kelas tidak sesuai dengan buku pedoman DDC maka akan menyulitkan pustakawan dan pemustaka dalam mencari buku atau koleksi yang mereka butuhkan. Selain itupula, ketika mahasiswa PKL ragu dalam menentukan subyek buku, disarankan untuk bertanya kepada pustakawan yang ahli dalam bidang tersebut. Atau jika memang benar-benar tidak ada di buku pedoman DDC, dapat menggunakan nomor kelas yang mendekati subyek tersebut.

Upaya yang terakhir adalah memberikan pelatihan-pelatihan kepada seluruh pustakawan lebih sering lagi minimal satu bulan sekali dengan tujuan kedepannya mereka dapat bekerja lebih professional sesuai dengan bidangnya, terutama yang bertugas dalam bidang pengolahan.

\section{G. PENUTUP}

\section{Kesimpulan}

1) Proses pengolahan bahan pustaka yakni inventaris meliputi pengecekan buku dalam kondisi baik dan lengkap, memberikan stempel kepemilikan perpustakaan, mencatat nomor buku induk. Selanjutnya mencari subyek untuk menentukan nomor kelasnya. Proses selanjutnya, katalogisasi yang menggunakan system terbaru yakni INLISLITE versi 3.1 dimana ketika selesai menginput data buku akan langsung muncul kode buku, warna sesuai nomor kelas dan barcode. Langkah selanjutnya memberikan kelengkapan buku seperti sampul buku, kartu buku, kantong kartu buku dan slip pengembalian, dan shelving.

2) Kendala-kendala yang terjadi diantaranya adalah masih kurangnya pustakawan yang berpengaruh dalam pengolahan, kurangnya anggaran, perbedaan nomor kelas, koleksi terbitan lama.

3) Adapun strategi yang dilakukan adalah memaksimalkan dan mengajukan penambahan pustakawan, memberikan pelatihan atau pendidikan untuk pustakawan, menambah jumlah anggaran, bekerjasama dalam menentukan nomor kelas.

\section{Saran}

1) Semoga kedepannya pustakawan lebih memperhatikan kendala yang dihadapi dalam proses pengolahan yang mengakibatkan pengolahan bahan pustaka menjadi terganggu dan lambat dan menjadi pembelajaran untuk kegiatan pengolahan di masa mendatang.

2) Kedepannya pustakawan bisa lebih bekerjasama dalam proses pengolahan, agar kegiatan dapat berjalan secara efektif dan efesien.

3) Melakukan pengangkatan pustakawan dengan tujuan agar pengolahan dalam berjalan dengan sebaik mungkin. 


\section{DAFTAR PUSTAKA}

Hamakonda, Towa P., J.N.B Tairas. 2016. Pengantar Klasifikasi Persepuluhan Dewey.

Jakarta:Penerbit Libri

Mustafa, Badollahi. 2010. Materi Pokok Promosi Jasa Perpustakaan.Jakarta : Universitas Terbuka

Narbuko, Ahmadi. 2005.Metedologi Penelitian. Yogyakarta : Pinus Rahayu, Lisda., dan Ramatun Anggraini Kiemas. 2013. Materi Pokok Pelayanan Bahan Pustaka. Jakarta : Universitas Terbuka

Rahayu, Lisda. 2015. Materi Pokok Layanan Pepustakaan. Tangerang Selatan : Universitas Terbuka

Sembiring, Sentosa. 2008. Himpunan Perundang Undangan Tentang PERPUSTAKAAN. Bandung : Nuansa Aulia

Suhendar, Yaya. 2007. Pedoman Katalogisasi : Cara Mudah Membuat Katalog Perpustakaan Jakarta : Kencana Prenada Media Group

Sumiati, Opong. 2010. Pengantar Ilmu Perpustakaan : Bahan Ajar Diklat Pengenalan Pengelolaan Perpustakaan. Jakarta : Perpustakaan Nasional RI.

Suwarno, Wiji. 2014. Perpustakaan dan Buku : Wacana Penulisan \& Penerbitan. Jogjakarta : Ar-Ruzz Media

Suwarno, Wiji. 2010. Ilmu Perpustakaan dan Kode Etik Pustakawan. Jogjakarta : Ar-Ruzz Media

Suwarno, Wiji. 2009. Psikologi Perpustakaan. Jakarta : CV. Sagung Seto

Yulia, Yuyu., Janti G. Sujana., dan B. Mustafa. 2014. Materi Pokok Pengolahan Bahan Pustaka.

Jakarta : Universitas Terbuka 